

An Interdisciplinary Journal

ISSN: 2091-0479

Department of Languages and Mass Communication School of Arts

Kathmandu University

Bodhi, 4 (1), 18-47. ISSN 2091-0479. (C) 2010 Kathmandu University 


\section{The Strength of Weak Ties: Role of Networks in Nepali Migration to South and Southeast Asia 1900- 2000}

- Lopita Nath

\section{Introduction}

The formation, role and the dynamics of the migration networks and their institutionalization underlines the importance of the historical analyses of the migration phenomenon. Nepali migration in the twentieth century to countries of South and Southeast Asia depended entirely on the networks established by the Gurkha soldiers settled overseas which provided the migrants with support at various stages of their migration initiative. These networks founded on the support of compatriots represented institutions of local origin, beyond caste and class barriers - "the strength of the weak ties", which resulted in an enlargement and enrichment of the networks, as well as increasing and sustaining migration flows.

In the last decade, the Government of Nepal had declared that migration of the Nepalis for labor and employment abroad was the backbone of Nepal's economy and the highest revenue earner. The migration of the Nepalis out of their homeland is over two and a half centuries old. This began with the recruitment of the Gurkha soldiers in the nineteenth century by the British East India Company for service in the British Indian Army. These Gurkha soldiers belonged to the ethnic Nepali communities of the Gurung, Magar from Western Nepal and Limbu and Tamang from Eastern Nepal, termed as martial by the British, and derived their name from the Gurkha ruler who established a unified Nepali state in $1768^{\mathrm{i}}$. The colonial government began to recognize their usefulness to the Empire as they proved themselves very hardy and versatile workers and sent them wherever the British were involved in any aggressive action, sometimes as far as China, Crimea, Greece and South 
Africa. Soon the British colonies in India, Hong Kong, Malay, Mandalay, etc. became areas out of their homeland where Nepali settlements became visible as many of these Gurkhas were stationed in these areas. These early migrations set the trend for later migrations. Notably, the migration decisions of the Nepalis reflect the colonial history of Asia with many Nepalis opting for destinations in the former British colonies of India, Hong Kong, Malaysia, etc. Even when opportunities for military jobs began to decline after the British departure from South Asia and finally with the handing over of Hong Kong to China in 1997, other temporary non-military jobs have become popular and decide migration destinations.

This article aims to assess the role of migration networks in the continuing and sustained migration from Nepal to countries of South and Southeast Asia. It also examines the role of these networks in encouraging migration flows, settlement and community formations in the country of destination. My argument rests on two points. First, the Nepali migration in the twentieth century depended largely on the networks established by the Gurkhas settled overseas which provided the migrants with support at various stages of their migration initiative. Second, these networks founded on the support of compatriots represent institutions of local origin, beyond caste and class barriers - "the strength of the weak ties" (Guilmoto ,et.al., 2001, p.150), which resulted in an enlargement and enrichment of the networks, as well as increasing migration flows. I analyze these issues by focusing on the migration networks in the case of the Nepalis: the Gurkha connection in India and Southeast Asia.

\section{Migration networks theory: A historical perspective}

The Migration Networks theory applied by Massey to his study of Mexican migration to the US, defines these networks "as sets of impersonal links that link migrants, former migrants, and non-migrants in origin and destination areas through bonds of kinship, friendship, and shared community origin" (Light, et.al.,1990). They convey information, provide financial 
assistance, facilitate employment and accommodation and give support in various forms, including the most needed personal and emotional support for adjustment in a situation of cultural marginality in the destination country. These reduce cost and uncertainty of migration and thereby facilitate it ${ }^{\text {ii }}$ (Massey et al, 1998, pp. 42-43). These networks play the role of a social capital which provides the connections needed to migrate safely and cost-effectively. "It is well known that most migrants follow 'beaten paths' and go where their compatriots have already established a bridgehead, making it easier to find work and lodgings and deal with bureaucratic obstacles" (Castles, 2002, p.1143). These connections have had the effect of shaping migration flows by making them less risky for individuals by circulating information among potential migrants and also feeding subsequent migration.

Although this theory had been quite effective in explaining the trends of Mexican migration to the US, studies by William Frey (2006) and by Johnston and Light (2007) have mentioned that the migration networks theory does not explain why Mexican migrants have opted to settle in non-traditional destinations and are moving into areas where former migrants had not ventured. However, in non-American cases of migration, particularly in this study of Nepali migration to South and Southeast Asia, migrants are seen to have made destination decisions based on connections.However, there have been a few deviations from the general rule where immigration policies of the government as well as employment opportunities have also guided immigrant destinations, as in the case of Nepali migration to Japan and South Korea.

The above study provides an explanation for the continuing and sustaining migration of the Nepalis into South and Southeast Asia. Despite the macro-push factors that never cease to abate in the case of Nepal (from the early economic problems, exploitation and discrimination of the Nepal government to the Maoist insurgency), the pull factors have changed and so have the composition and character of the migrant population. 
Military jobs are no longer the common option and people are migrating for a wide range of jobs mostly in the laboring and construction sector as well as domestics, especially for women migrants. But that does not undermine the importance of connections and networks. The Gurkha connection has been from time to time used and exploited, while other organizations have emerged, like the Non-Resident Nepali Association (Global), All India Gorkha League ( India), All India Madhesi Students Association ( India), Far East Overseas Nepali Association- FEONA (Hong Kong), The Gurkha International Group ( Hong Kong), Gorkhali Association ( Hong Kong) and many others. These organizations have helped not only in providing links to migrants but have aided both in settlement and community formations and increasing earning opportunities where other options fail.

\section{Out-migration from Nepal to South Asia: Following the Gurkha trail}

The political and social history of Nepal has largely been formed by waves of migration from the south and north at different periods of time. The most important political development in Nepal's history, the accession of the Gurkha ruler Prithvi Narayan Shah and the establishment of the unified Nepal in1768 iii (Nath, 2003, p.24) was the culmination of a northward migration of the Rajput rulers from the Indian states of Rajasthan, fleeing Mughal persecution and establishing a Hinduised rule in the centre of Nepal. In fact, Nepal's population composition marked by large ethnic diversity, of Mongoloid as well as Caucasoid races as well as their admixture, has been formed by waves of migrations at different periods of their history. These movements of people had been in existence even before the boundaries of Nepal with its contiguous nations of India and China had been defined. This is evident from the cross-cultural Hindu and Buddhist influences in Nepal. Nepal's present boundary with India evolved after the Peace and Friendship Treaty of 1816 (following the First Anglo-Gurkha War) and completed in 1861 after the Far 
Western Terai ceded to the British East India Company in 1816, was returned to Nepal (Kansakar, 2003, p. 85). This later developed into the Indo-Nepal Peace and Friendship Treaty of 1950 which while specifying boundary limits also laid down parameters to guide the movement of population between the two countries. The border agreement with China was first signed in October 1961 and finalized in 1982, based on scientific and accurate ground surveys as well as latest satellite photographs (Kansakar, 2003, p. 85). The Nepal-China boundary, which had been open earlier, became closed after 1950, while the Nepal-India border has remained open for the nationals of both countries. This open border with India has facilitated an even greater movement of people than before.

The first professional out-migration from Nepal to South Asia was after the first Anglo-Gurkha war (and the Treaty of Sugauli) in 1816. General Ochterlony, the British commanding officer, first employed Gurkhas, when he organized a 'Corps of deserters to assist him against Amar Singh Thapa in 1816' (Whelpton, 2005, p. 43; Hussain, 2003, p. 68) ${ }^{\text {iv }}$. The Nepal government was strictly against the recruitment of the Gurkhas in its own territory and instituted strict punishments, even executions and confiscation of properties on those who decided to join. Brian Hodgson, who took over as Resident in 1832, decided to change Nepal's anti-British attitude, by encouraging commerce and also by employing her 'surplus military manpower' in the East India Company's forces (Whelpton, 2005, p. 43; Hussain, 2003, p. 68). In 1839, as a result of a special treaty between the government of Nepal and the Sikh (Khalsa) Government Nepalis were recruited in the Sikh army (Kansakar, 2003, p. 93). These new recruits went to Lahore the capital of the Sikh government in Punjab and since then the Nepalis serving in foreign armies were called 'Lahure' (one

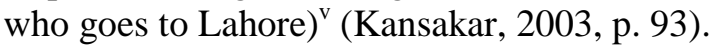

So, thus began a liaison which was to continue to the present century. After the Sepoy Mutiny of 1857 the British Government realized the need for more people from Nepal to 
serve the British army. Since Nepal was still against recruitment, to encourage volunteers, the British set up recruitment centers on the Indian side of the Indo-Nepal border and also encouraged the Gurkhas to migrate with their families. This led to the emergence of Nepali settlements along the hilly areas of North and Northeast India, "from the borders of Afghanistan eastward to Burma, such as Abbotabad, Muree, Bakloh, Simla, Bhaksu, Dharamsala, Darjeeling, Kalimpong, Shillong, Mandalay, etc.” (Kansakar, 2003, p. 93).

In Northeast India Gurkhas took part in the Sylhet operations as a part of the Cuttack Legion, later known as the Assam Light Infantry. Thereafter, with the Anglo-Burmese war of $1824-26$, the Gurkhas, described by Lord Bentinck as "brave and energetic" and 'the most eligible', came to replace the Manipuris in the Company's forces in the Northeast of India. ${ }^{\mathrm{vi}}$ And within a period of six years $(1833-1839)$ nearly one-third of the battalions in the Assam Light Infantry came to be composed of Gurkhas. In 1835, the 'Cachar Levy' which eventually grew into the 'Assam Rifles' liberally enlisted the Gurkhas, constituting half the Assam Rifles. As early as 1865, the Nepali Khukuri replaced the short sword and the crossed Khukuri became the emblem of the Assam Rifles (Shakespeare,1929, p.23). This continues till date. During the First World War about 243,000 men from Nepal enlisted in the British army, while an additional 160,000 were recruited during the Second World War (Gurung, et.al, 2004, p.101). With the independence of India in 1947, the Gurkha unit of the British Indian army was divided between India and the United Kingdom. The British retained half later reducing its size, while India retained the original size of the regiment. 'As of early 2003, there were about 3,500 Nepalis serving in the British Gurkha army and about 30,000 pensioners, while there are 48,000 Nepalis serving in the Indian army and about 150,000 pensioners' (Gurung, et.al, 2004, p.102).

Others, mostly unskilled, followed the footsteps of the Gurkha soldiers, migrating for the purpose of labor. British colonial 
enterprise in South Asia was one of economic exploitation of the untapped natural resources which also led to new innovations and experimentation in agriculture, specially the commercial variety. Tea and rubber plantations required intensive manual labor and Nepal became a prime labor generating country. They were bonded, contractual as well as voluntary recruits trying to escape the then economic discriminations and overpressures of taxation under the Rana regime in Nepal. The main destinations were India, Malaya, Burma, China, Tibet, and after 1947, Pakistan. In the last two decades the political situation in Nepal was disturbed due to the Maoist insurgency which created further economic and social instability in the country. This led to an increased migration from Nepal in recent times.

In India, the Nepalis headed for the areas on the North and Northeastern border areas, where the British had allowed Gurkha settlements. The Kumaon and Garhwal hills, the hilly areas of Uttar Pradesh, Darjeeling in North Bengal, Sikkim, Northeast India, all became the key destinations for the Nepali laborers. They worked in the tea plantations in Darjeeling and Assam and were also seen working in an assortment of jobs in the British Hill stations in North India. "The Gurkhas were useful for any odd and sundry jobs, as well as specialized jobs assigned to them. A capable, cheerful and alert people and are essentially a virile race. Though quick tempered and keen to resent an injustice, they are remarkably willing and loyal, if treated with consideration... Though small in stature, these Nepalese have big hearts... Naturally vigorous, excitable and aggressive, they are very law abiding..." these comments recorded by L.S.S. O'Malley, editor of the Bengal District Gazetteers, aptly described the Nepali migrant in India (O'Malley, 1984, p. 44). The versatility of the Nepali as agricultural labourer, grazier or pastoralist, porter, watchman, gardener, driver, mechanic, plumber, cleaner, pony cart driver, bus conductors etc. made them easily available to any private or corporate agency for any miscellaneous work on a modest compensation. 
They soon spread to all the newly emerging cities and townships where work was easily available. This migration continued, even more so after India's independence, facilitated by the Indo- Nepal Friendship treaty of 1950 and the availability of jobs necessitated by the modernizing economy of independent India. With the expansion of construction works, commercialization, advent of modest industrialization and extension of transport and communication, there was an increasing demand for the semi-skilled labor. The Nepali laborer always willing and available more than met this need halfway and migration to India accelerated. The Population census of Nepal in 1952/54 recorded 79.4 percent immigrants to India. This number continued to increase over the years, the census reports recording 93.1 percent in 1981.In 1991, however, the percentage of the total immigrants declined to 89.21 percent, which further declined to 77.28 percent in 2001 (Kansakar, 2003, pp.111-112). This is indicative of a changing trend of immigration to other countries beyond India.

\section{The "Gurkha Connection": Migration to South East Asia a newly developing trend}

The "Gurkha Connection" as it has come to be referred to in historical and other scholarly literature has indeed become the guide for destination decisions made by many migrants from Nepal to countries other than India. For more than 180 years the Gurkha brigade had established a tradition of serving in foreign companies in foreign lands. After India's independence and the division of the Gurkha army between India and the United Kingdom, the main camp for the British Gurkha troops was established in Malaya in 1948. The number of the Gurkha troops increased during the period of Communist insurgency in Malaya from 1948-56 when the British recruited additional Nepalis to serve in the Gurkha army (Kansakar, 1982, p. 92). For the next twelve years from 1948-60, they were involved in quelling the Malayan Emergency against the communists. In 1962 they were deputed in the Revolt in Brunei, followed by the confrontation against Indonesia for the next four years. And 
after 1966, they found themselves engaged in internal security tasks in Hong Kong during the Cultural Revolution in China. From 1967 onwards as a part of changing defense commitments, there began the process of reducing the Gurkha Brigades in the East. In the early 1990's there were about and only over 7,400 Gurkha soldiers in the British army, in Hong Kong and Brunei, accompanied by over 4,800 dependents and nearly 150 civilians employed in various services as teachers, religious instructors, goldsmiths and midwives (Collet, 1994, p.98).

Gurkha recruitment on a massive scale began to decline further when the British following the decision to return Hong Kong to China reduced the Gurkha Brigades in 1997. Edward A. Gargan (1996), in an article published in the New York Times, Hong Kong, writes,

By the end of November, virtually all of 707 men in the Royal Gurkha Rifles, the last Gurkha force in Hong Kong, will leave their barracks in the Malaya Line, as their encampment is known, and head to England. When they withdraw from Hong Kong, it will mark the final chapter for British Gurkha regiments in Asia, the end of Britain's 156-year colonial presence on the Chinese coast, indeed the end of Britain's imperial adventures in Asia.

The Gurkhas were given the option to return to UK, but their wives had to go back to Nepal.This in most cases became a deciding factor as many did not wish to leave their wives or even Hong Kong. "There's no space for our wives," said Lance Cpl. Ram Bahadur Malla. "My father is an ex-army. He was in the Gurkhas, and he was based in Hong Kong. So Hong Kong runs in our family. Of course we'd like to stay here, but we cannot" (Gargan, 1996). The Gurkhas were discharged prematurely and while many returned to Nepal, others decided to remain overseas serving the Sultan of Brunei as security guards $(2,200)$, as policemen in Singapore (1000) and also as suppliers of top security on contract to business organizations 
and private homes in Hong Kong (Yamanaka, 2000). Nepalis working as security personnel were found in almost all the former British Colonies, beyond India and as far as Brunei, Singapore and Hong Kong. Many decided that working as security guards was more remunerative than returning to a pension in Nepal, and they can be seen outside homes and luxury apartment complexes across the territory. "As for a legacy, I think we leave behind an asset to the security industry and on a lighter note, a lot of broken hearts," said Colonel Rawat (Gargan, 2006).

That was not the only legacy they left behind. The remittances sent by these Gurkhas made large contributions to the upliftment of the otherwise rural and undeveloped economy of Nepal, reaching almost 20 percent of Nepal's yearly foreign exchange (Yamanaka, 2000). But the greatest impact of the Gurkhas to the home country were the effects of changes on the lifestyle and living conditions of the Gurkhas themselves. As mentioned by Collet, serving life in the western societies, have made the soldiers and their dependents accustomed to a life in a better and beneficial environment. "The return to Nepal can be a shock to these men and their families. Many men seek continued service abroad in Brunei, the Gulf or other countries. Some continue to educate their children abroad and even settle overseas themselves" (Collett, 1994, p. 103). This has led to the emergence of Nepali settlements and communities in these areas of Southeast Asia.

Nigel Collett who now heads the Gurkha International Group, a Company which recruits retired Gurkhas for service in the security industry in Southeast Asia and Nepalis for service overseas, in an interview remarked,

The Gurkha connection is, pace the post-colonial theories of the likes of Lionel Caplan, who seems to have been way wide of any real mark, a reality. The Army created a link in 1817 which has lasted till today because it was mutually beneficial. Britain got good soldiers (there is no myth there); the innate quality of Gurkhas has always 
been higher than their British equivalent due to the lack of alternative employment opportunities in Nepal. On top, of course, of the usually cited issues of physical stamina and fitness due to living in the mountains, a simpler view of life, a readiness to accept discipline due to hierarchical society upbringing, ready acceptance of hardship due to background, and the requisite degree of tough bravery needed in war time. The Gurkhas got a comparatively much better living than any available in Nepal, travel, foreign service and maybe settlement and status not available at home. On top of these practicalities are the emotional ties the British Army spends most of its daylight hours fostering; tradition, family, history, honour, all in the melting pot of creating an esprit de corps. In Gurkha regiments, service is often of three or more generations, and marriage is often within the regimental family. This adds to esprit and cohesion and is a real deterrent to failure. The genuine feeling that exists in the Gurkha connection is seen in the flourishing regimental associations which survive across the world. Men remain in them to remember their military past and to meet their comrades. I am adviser to the Hong Kong Branch of the 6th Queen Elizabeth's Own Gurkha Rifles Association, so have this at first hand. (Nigel Collett, interview, July 18, 2008).

This has also created a culture of immigration among the Nepalis. "Boys grow up in the family's expectation that they will follow their forefathers tradition of Gurkha service in foreign lands. Girls are encouraged to marry affluent retired military pensioners or soldiers..." (Yamanaka, 2000, p. 65). And even though the recruitment of the Gurkha soldiers declined in the 1990's, immigration became the answer to the many problems that Nepal is suffering from and large numbers continue to leave Nepal is search of jobs in response to the rising demands for labour in many Asian countries. 
The Population census of Nepal of 1952/54 records that the second important destination for large number of Nepali immigrants was Malaya, this being the earliest recorded data on immigrants from Nepal. Kansakar mentions that since the colonial period the Nepalis worked as labourers in the sugar, rubber and palm plantations in Malaya. The Population Census of 2001 records a decline, with Malaysia representing the sixth largest destination for Nepali immigrants after the Middle Eastern countries and Hong Kong. This changing trend of Nepalis heading for the Southeast Asian countries other than India became perceptible in about the 1980's when the Census of 1981 began to record Nepali immigrants to China and other Asian countries (Table 2). By 1991 the records clearly indicated migration to countries of Southeast and East Asia, in addition to the Gulf countries. The census of 2001 gives the statistics for almost 17 individual Asian Countries (Table 4.) clearly defining the changing trend. According to the Population Census of 2001, Hong Kong is the fourth largest destination of the Nepalis followed by Japan, Korea, China and Singapore amounting to a total of 2.83 percent in the Asian countries. The percentage of "absentee population" in 2001 other than India was 23 percent and a total of 173,000 persons (Gurung, 2004, p.103).

Table1: Showing the Countries of Destination of the Emigrants from Nepal-1952-54

\begin{tabular}{|l|l|l|l|l|l|l|}
\hline Countries & Persons & $\%$ & Male & $\%$ & Female & $\%$ \\
\hline Total & 198120 & 100.0 & 173919 & 87.8 & 24501 & 12.2 \\
\hline India & 157323 & 79.4 & 137942 & 87.7 & 13381 & 12.3 \\
\hline Malaya & 6621 & 4.2 & 5657 & 85.4 & 964 & 14.6 \\
\hline Burma & 1849 & 0.9 & 1584 & 86 & 258 & 14 \\
\hline $\begin{array}{l}\text { China\& } \\
\text { Tibet }\end{array}$ & 422 & 0.3 & 361 & 85.5 & 61 & 14.5 \\
\hline Pakistan & 153 & 0.1 & 138 & 90.2 & 15 & 9.8 \\
\hline Others & 31759 & 20.2 & 27937 & 88.0 & 3822 & 12.0 \\
\hline
\end{tabular}


Table 2: Showing the Countries of Destination of the Emigrants from Nepal-1981

\begin{tabular}{|l|l|l|l|l|l|l|}
\hline Countries & Total & $\%$ & Male & $\%$ & Female & $\%$ \\
\hline Total & 402977 & 100.0 & 328448 & 81.5 & 74529 & 18.5 \\
\hline India & 375196 & 93.11 & 307946 & 82.1 & 67290 & 17.9 \\
\hline China & 265 & .07 & 225 & 84.9 & 40 & 15.1 \\
\hline $\begin{array}{l}\text { Other Asian } \\
\text { Countries }\end{array}$ & 9054 & 2.25 & 7068 & 78.1 & 1986 & 21.9 \\
\hline Others & 18462 & 4.58 & 13209 & 71.5 & 5253 & 28.5 \\
\hline
\end{tabular}

Source: Population Census of Nepal 1981

Table 3 Showing the Countries of Destination of Emigrants from Nepal -1991

\begin{tabular}{|c|c|c|c|c|c|c|}
\hline Countries & Total & $\%$ & Male & $\%$ & Female & $\%$ \\
\hline India & 5487243 & $\begin{array}{l}89.2 \\
1 \\
\end{array}$ & 492078 & 83.8 & 95164 & 16.2 \\
\hline $\begin{array}{l}\text { South } \\
\text { Asian }\end{array}$ & 4977 & .76 & 3652 & 73.4 & 1325 & 26.6 \\
\hline Arab & 6345 & .96 & 6345 & 93.8 & 394 & 6.2 \\
\hline $\begin{array}{l}\text { Other } \\
\text { Asian }\end{array}$ & 20024 & 3.04 & 16364 & 81.7 & 3660 & 18.3 \\
\hline Europe & 6404 & .97 & 4581 & 71.5 & 1823 & 28.5 \\
\hline $\begin{array}{l}\text { North } \\
\text { America }\end{array}$ & 2150 & .33 & 1484 & 69.0 & 666 & 31.0 \\
\hline $\begin{array}{l}\text { Other/ } \\
\text { not stated }\end{array}$ & $\begin{array}{l}581 / \\
30566\end{array}$ & $\begin{array}{l}.09 / \\
4.64\end{array}$ & $\begin{array}{l}445 / \\
23446\end{array}$ & $\begin{array}{l}76.6 / \\
76.7 \\
\end{array}$ & $\begin{array}{l}136 / \\
7120\end{array}$ & $\begin{array}{l}23.4 / \\
23.3\end{array}$ \\
\hline
\end{tabular}




\section{Table 4: Migration to South/Southeast Asia in 2001}

\begin{tabular}{|l|l|l|}
\hline Countries & Total & Percentage \\
\hline Total abroad & 762181 & 100 \\
\hline India & 589050 & 77.28 \\
\hline Pakistan & 552 & 0.09 \\
\hline Bangladesh & 952 & 0.12 \\
\hline Bhutan & 610 & 0.10 \\
\hline Sri Lanka & 201 & 0.03 \\
\hline China & 1354 & 0.18 \\
\hline Korea & 2679 & 0.45 \\
\hline Japan & 3726 & 0.63 \\
\hline Hong Kong & 12001 & 1.57 \\
\hline Singapore & 3363 & 0.44 \\
\hline Malaysia & 6813 & 0.89 \\
\hline
\end{tabular}

Source: Vidya Bir Singh Kansakar, 'International Migration and Citizenship in Nepal" (Population Monograph, http://www.cbs.gov.np/Chapter 14), 110-112.

Migration from Nepal became much more defined since the enactment of the Foreign Employment Act, 1985. This act aimed at controlling foreign migration from Nepal also played the enormous role of keeping a check on the recruiting agencies. The Ministry of labor in Nepal recorded as many as 214,839 registered, legal emigrants from Nepal in May 2002. Besides the Middle Eastern countries, the main Southeast Asian destinations were Malaysia (52,581), Republic of Korea $(3,040)$, Hong Kong $(1,639)$ (Gurung, 2004, p. 103). In recent years the government of Nepal records that annually about 50,000 people migrates to foreign countries other than India. Gurung and Adhikari (2004) writes that, 'According to a press release of the ministry of labour in January 2003,35,462 workers went abroad for employment in 1999-2000, which increased to 55,025 in $2000-01$ and 104,739 in 2001-02. The increase in the 1999-2000 periods was 57 percent and 58 percent in 2001-2002." Although government sources record about 250,000 Nepalis working in foreign destinations, a study 
conducted by the Nepal Institute of Development Studies 'shows that around 700,000 Nepalese were working in foreign countries in 2003' (Gurung, 2004, p.103). This number does not take into account the large number of undocumented workers who have migrated either illegally or hold British or Hong Kong citizenship and fall into different categories.

A study conducted by the Nepal Institute of Development Studies estimated that most of the migrants were engaged in manual labor jobs in industry, construction work, agriculture, or the service sector. This study, which was the first systematic study conducted on Nepali foreign labor, mentions that most of the migrants were engaged in the $3 \mathrm{D}$ jobs (dirty, dangerous and demanding). In 1997 it was estimated that about 40 percent of the overseas Nepalis worked and lived in Hong Kong, Singapore and Brunei. Even Collett remarked that the numbers were just estimates; "though there are thought to be some 20,000 Nepali people here now (this is an estimate; the Immigration Department keeps the figures secret and the Nepali Consul General doesn't know). The number of real ex-British Gurkha soldiers has fallen sharply since the UK Government allowed settlement there in 2005. Many of the remaining Gurkhas are in their 60s and will return to Nepal on final retirement (usually at 65 here). The few younger men are in their 40s and are left here only because for some reason they do not qualify for UK entry. I would guess there are less than 1000 Gurkhas left here at most and this number declines rapidly." Another source, the Far East Overseas Nepali Association (FEONA), believes that, although the official figures record only 12,564 persons, the total number is close to 30,000 as a large number of them are undocumented.

Hong Kong had remained by far the most favored destination until 2005, when the Hong Kong Government was no longer issuing any more visas. Stephen Frost, in his article on "Nepalese labourers in the construction sector" in Hong Kong, mentions that the construction sites in the Hong Kong Special Administrative Region (SAR) of China significantly uses 
Nepalese migrants. "An almost invisible community within the territory's non-Chinese population, Nepalese nevertheless comprise a greater proportion of the workforce on building sites than their statistical presence in official census figures might suggest" (Frost, 2004). The Nepali workers in Hong Kong constitute a very small group, only about $5.1 \%$ according to the Hong Kong Census reports in 2001, yet they are ranked seventh among the ten largest non-Chinese communities in the country (Frost, 2004) ${ }^{\text {vii }}$. The Nepalis in Hong Kong are usually permanent citizens and have the right to abode because of their Gurkha connection, but most of them are recent migrants from the post-1997 period.

Although Malaysia had large Nepali migrants during the colonial period working in the private sectors, Nepali migration in the present times only picked up after February 2001, when the Malaysian government officially "opened" its labor market to Nepali workers. 'Within six months, over 12,000 labor migrants had left for Malaysia, and a year later Malaysia was hosting some 85,000 Nepali migrant workers' ( Seddon, 2005) Another news report on Southeast Asian Migration mentioned that the "Nepali government is asking the Malaysian Government to allow 300,000 Nepali workers to work in Malaysia, up from the current 32,000" (The Star, 2002). It is interesting to note that subsequent to the Foreign Employment Act, 1985, the government of Nepal, starting with Malaysia and Hong Kong, entered into bilateral agreements with 20 destination countries.

But as Seddon (2005) writes, "Foreign labor migration from Nepal is still largely a privately organized affair in which individuals make use of their own personal networks or make arrangements through a number of private, governmentregistered manpower or recruitment agencies." One such network has been the Gurkha settlements in overseas destinations. 
Nepali migration networks: Institutionalization of migration

The Gurkha settlement has led to the establishment of strong migration networks throughout South and Southeast Asian region where the troops had been stationed (Yamanaka, 2000). These networks established by the Gurkha presence, (for example the Nepal Ex-servicemen's Association formed in 1997), became the most solid support for maintaining migration flows. Organizations such as Non-Resident Nepali Association (Global), Far East Overseas Nepali Association- FEONA (Hong Kong), Gurkha International Group ( Hong Kong),Gorkhali Association ( Hong Kong),etc., have played the role of serving as connections that migrants seek when they are trying to immigrate. The Foreign Employment Act of 1985, apart from setting up a mechanism for controlling foreign labor migration also contained provisions for licensing foreign employment or recruiting agencies (Gurung et al., 2004, p.104). These recruitment agencies have emerged as organized bodies licensed by the government who for a fee locate vacancies, fix salaries, take care of the paper work, insurance and other such formalities needed to migrate abroad. However, it is an established fact that the fees charged by these agencies are exorbitant, and cheating migrants are not uncommon. But individuals do have the option to migrate on their own and they often do, although the government is of the opinion that the success rates among individual migrants who migrate on their own are fairly low.

However, most of these individual migrants are not entirely on their own and are dependent on networks, most of them formed probably during the historical past, with the Gurkha settlements. In India, parts of Northeast India, Shillong, Darjeeling, Kumaon, Garhwal, Simla, Dehra Dun, etc., have large concentration of Nepali settlements and most of these have originated and grown with the support of the retired Gurkhas. After release from service, they settled down in and around the district towns and strategic location on the hills. The Assam 
Rifles rehabilitated its Gurkha soldiers in various sites in the northeast India, for example, at Sadiya in Assam, Mantripokhari in Manipur, Aizawl in Mizoram, Mokokchung in Nagaland and also at Arunachal Pradesh, Meghalaya and Tripura $^{\text {viii }}$. Compact pockets of Nepali settlements in different parts of the region have emerged. Most of these residents have displayed a tremendous capacity of assimilating with the local people, contract marital alliance and also become a part of the local economy. These settlers with their peasant background and military training have acquired the image of loyal citizens with pro-establishment attitude towards the Government. This reputation for integrity and loyalty made the Gurkhas important networks from which the labor was hired by the locals in the destination country. In India every apartment or office had a night or security guard who was called a Gurkha, and was, in most cases, a retired Gurkha serviceman. "Gurkha soon evolved as a brand name for integrity and loyalty as the batman to the British officer became the prototypical household help" (Dixit, 1997, p.15). Over the years being a Nepali was also a criterion for recruitment.

Even for other jobs, especially in India, where most immigrated on their own, networks played a very significant role. There is a tendency of the migrants from certain areas in Nepal to go to specific locations following connections and increasing access to jobs and reducing risks. Dixit (1997) indicates that, in general, "the population of the poverty-stricken western hills...migrates to adjacent areas in India.[But] besides going to the nearby plains, some Nepalis from the far west also hike across into Uttarkhand, whose own men folk migrate to Delhi to find better work. In Uttarkhand, Nepalis [called Dotyals] serve as coolies in hill stations like Nainital and Mussoorie and carry loads for pilgrims... at holy locations such as Gaumukh and Kedarnath." From the far west, "quite a number...go to serve as coolies and watchmen in Nainital, Almora, and the other border towns of Kumaun" (pp.10-18). Some go as far as Patna, or nearby to Kolkata, Assam and the Northeast Indian states. 
In a study conducted on the immigrants from Far Western Nepal to Delhi, Susan Thieme (2007) emphasizes how these networks facilitate migration and integration of the migrants. Thieme defines these networks as "a durable network or more or less institutionalized relationships of mutual acquaintance and recognition" and writes that most of the migration process, access to jobs, remittance transfer and management of financial needs are facilitated by kin and migration networks. Most migrants (Seddon, et.al., 2002; Himal, March, 2003), work in the informal sector in India. Most of them hold more than one job, gaining access to these jobs through former migrants from the same area or region, and the insecurity of the informal job sector is more than outweighed by the flexibility that the migrant enjoys in adapting the work to their migration and lifestyle needs. It is most common to see husbands arranging jobs for their wives, migrants handing over jobs to close relatives and friends and sometimes this is done for a price, which is satisfactory for all parties concerned. This allows the migrants the flexibility of returning home when they wish to do so, with some money from the payment for the job, and the employer is not without a worker, with recommendations from his former employee, and the new migrant gets a job. These "job chains" act as very strong networks giving migrants a security in their job searches when they migrate to these new lands.

These networks also provide assistance at integration and settlement and community formation. In the same study, Theime (2007) mentions that the living conditions of Nepali migrants in Delhi are in sharp contrast to what they were used to at home or even in cities like Kathmandu in Nepal. Most migrants prefer to work and live in the same vicinity. "Men establish their own households in Delhi, with multiple forms of cohabitation and overlapping social units. They share houses with not only their closest and extended family members but also with co-villagers from the same caste",ix (Thieme, 2007, p. 40). However, there have evolved other community organizations, like cooperatives and credit societies, which rise 
above caste restrictions. Thieme's study related to financial and credit institutions, notes, "Membership in cits and in many sosâities provides examples of the melting and merging of traditional structures in terms of caste and gender at the same time. Caste rules are merged, in the sense that cit members from all castes provide each other with the chance to have equal access to loans" (2007, p. 40). This is also the case with the participation in other community activities, where traditional structures are changed to meet the requirements in the destination country.

In Southeast Asia, the centre of these networks emerged in Hong Kong where about 10,000 Gurkhas and their families resided. In the present times this former British colony hosts the largest Nepali diaspora in the Far East. Nigel Collett, who is the Director of the Gurkha International Group in Hong Kong, mentioned in an interview,

My experience in Hong Kong is that settlement in the 1990s began clustered around military camps and quarters areas (Sek Kong, Kam Tin, Yuen Long) then spread out once the community had established itself. The Nepali community here lives almost everywhere, though there remain clusters, some in new areas like Mong Kok, Yau Mat Tei, Tsuen Wan, Sheung Wan and Wanchai.

The surge of Nepali immigration to Hong Kong increased greatly when the British government granted citizenship to an estimated 7,000 children of Gurkha soldiers. A substantial portion of these has returned to the former colony to work as unskilled laborers. Further, as mentioned earlier, the Nepali migrants in Hong Kong are given the right of abode because of the connection they had. After the transfer of Hong Kong in 1997, the Chinese Government issued the "right to abode" to the families of the Gurkhas. A Nepali child born in Hong Kong to Gurkha parents has the right to abode, as well as a spouse who is married to a former Gurkha soldier. This has a history. In Hong Kong, the main engine of settlement was the British 
Military Hospital, which produced Gurkha babies at a very high rate between the mid 60s and mid 90s, all of whom up to 1995 were eligible to settle here due to their place of birth. A large number of these children joined the army in their 20's and came back to Hong Kong in the 1990's as they were born in Hong Kong (Collett, July 21, 2008).

In the present times the G4S Gurkha Services Limited has emerged as the leading and largest provider of security services in Hong Kong over the entire Asia Pacific region (www.g4s.com/hk/hk-services). "G4S was first in the field. They are the descendants of a company formed by a Major Chris Hardy, who retired in Hong Kong in about 1993-4 and set up a guarding company, encouraged by the military authorities. He was quickly bought out and resourced by Jardines which turned the company into the most prestigious player. It remains the largest employer of Nepali guards, though nowadays almost all are civilians" (Nigel Collett, in an interview dated July 21, 2008). Another company, which has branch offices in UK and Kathmandu, The Gurkha International Hong Kong (Ltd.) under its director Lt. Col. Nigel Collett offers similar services (http://www.gurkha.com.hk). "I set GIMS up in 1994 to establish Nepal at sea, and added local guarding, body-guarding and driving services in Hong Kong to enable us to do so. G4S has tried to spread Gurkhas across Asia but has not made a success of this due to high costs (they need to pay real Gurkhas high wages which don't compete in local markets). They have had the greatest success with the new casinos in Macau, as have we. Our work at sea has, of course, spread us across the world," remarked Nigel Collett (July 21, 2008). The Company recruits from Nepal for service on the cruise liners all over the world, in Europe, America, Southeast Asia, etc. For the rich tycoons in Hong Kong, protection and security is the biggest need and having their very own Gurkha is the ultimate status symbol (Landler, 1998). 
The presence of the Nepalis in Hong Kong has become the networks for information for Nepali immigrants, as also a source for employers in the Southeast and East Asian region. Yamanaka (2000) writes, "In the late 1980s Japan enjoyed an unprecedented period of economic growth which resulted in a demand for massive unskilled labor force to be employed in jobs shunned by the Japanese. Nepalese visitors and migrants to Japan before 1988 saw a golden opportunity for employment there and sent the news to fellow Nepalis in Hong Kong" (pp.62-63). The migration networks formed by the Gurkha Connection have almost become institutionalized and constitute a system that has now been in existence since probably the first batch of retired Gurkhas began to settle in these areas out of their homeland. Nigel Collett, however, does not see this happening very much in the recent times:

Not so much. People who lived in Hong Kong travelled to Thailand and Brunei, but returned to Hong Kong and did not settle in these countries. "In my experience, all the Nepalis who came here or followed the Gurkhas stayed here, or went to England if they could. But as far as I know, none have gone off from here to other countries of Southeast Asia. In my knowledge the workers in Japan and South Korea are employed through agencies set up in Kathmandu. Hong Kong was a destination rather than as a transit point.

However, he is of the opinion that some of these workers, after they had finished working in Japan and South Korea, since they have temporary visas there and could not overstay, might have come to Hong Kong and there is a potential that they might have advised somebody. Makito Minami (2008), in her study on the Nepali immigrant workers in Japan, writes that most of the Nepalis coming to Japan around the 1989 might have entered by way of Germany, where Nepali tourists did not require a visa. "They could easily obtain a short-term visitor visa to Japan at the Japanese consulate in Hamburg" (p. 89). In the same study it is also mentioned that around the 1990's some Nepalis did enter Japan, by way of Hong Kong and South 
Korea. These migrants entered as short-term visitors or with transit visas and then infiltrated and stayed on in Japan. So although it is not definite that the Nepalis in Hong Kong are a source of information as Yamanka says, it cannot be totally ruled out.

Immigration to countries other than India was mostly dependent not only on linkages or "pathways of migration", but also on the historical connections established through experiences of migrations and employment. Seddon, et. al. (2002) write that foreign labour migration is most prominent in those areas of Nepal which had a history of emigration.

The Western and Eastern Hill regions, from which recruitment of the British Gurkhas began in the early nineteenth century, remain those from which labor migration (other than to India) is most significant today. Migration to East and Southeast Asia is dominated by men from these regions, as is employment in the army or security services in Britain, India, and elsewhere.

The migrants from the Western and Eastern Hills migrate to most of the Asian countries. It was expected that most migrations would go through the established agencies, but countries of Southeast Asia had become very restrictive on immigration policies, especially during the Asian Crisis of 1997-98 and there was an increase in the number of illegal immigrants. Although the situation has improved in recent years, immigrants depend on informal networks and personal connections to find jobs, and help in the adjustment and settlement process.

Migrants in most Southeast Asian destinations go through a tremendous adjustment process. Nigel Collett commented that, establishing the bona fides of applicants for settlement has been a major headache for the Hong Kong Immigration Department. Identities were sold in Nepal, and forged birth documents were also created, 
for large sums and it became apparent by about 1999 that there were many settlers with false identities. The Hong Kong Immigration sent an expedition to the British record Office in Pokhara to investigate and found they had admitted (according to information I had from the Nepali Consul General here of the day) that they had admitted almost twice as many as they should have. New spouses and dependents continue to arrive here even now, though to a lesser degree (Collett, Interview July 21, 2008).

In the light of the above situation the Hong Kong Government became very strict and implemented a ban on visas issued to Nepalis. "Even the consul cannot get diplomatic people to transit through here". Thus despite the right of abode, most Nepali immigrants, especially in Hong Kong after 1997, suffer from issues of visa ban, underpayment, excessive agency fees and long work hours and no rest days and other such discriminations. Most of these issues are due to ignorance of the Nepali workers of work conditions. However it is seen that most of the Nepali Domestic Workers (NDW) in Hong Kong, as they are called, turn to friends for advice and counseling. A survey conducted on the issue in Hong Kong, "revealed around $1 / 3$ would be confident in consulting friends (34\%), $15 \%$ would seek the support of both friends and migrant organizations, and a mere $1 \%$ would go to the Consulate". ${ }^{\circ}$ This advice and counseling is often provided by former migrants or even organizations like the FEONA, that have helped in many cases in conducting these studies.

Collett remarks that each of the different jobs has established different organizations in Hong Kong. Even within the jobs there are organizations that offer support. There are religious organizations, Buddhist and Christian, as well as welfare organizations. The welfare organizations offer support in several ways, especially to overcome the culture shock, accommodate new migrants into the community and set up schools for children. These organizations offer a very large 
system of self-help, driven partly because there is no help as a community from the government in Hong Kong. Even the British Consul is not interested (Nigel Collett, interview, July 21, 2008).

These networks established by the Gurkha presence in some cases, (for example the Nepal Ex-servicemen's Association formed in 1997) and by migrant workers in others, became the most solid support for maintaining migration flows. These networks founded above all on the support of compatriots thus represent an institution of local origin, covering several spaces from the village to the destination. They often rise above caste and class barriers, "the strength of the weak ties," which results in an enlargement and enrichment of the networks (Guilmoto, et.al., 2001, p.150). The ties that are used as links and exploited by the immigrants are not close relatives and can be as weak as someone that they probably knew from the same region. The networks provide migrants with support at various stages of their migration initiative: support for the project, identification of destinations, desirable times for migration, advance costs during migration, provide support for lodging and employment. The Gurkhas thus provided a strong institutional base for the migrants out of Nepal, providing the 'Human organization' needed for the migrants from the village to the destination (Guilmoto, et. al., 2001, p.150).

\section{Conclusion}

The formation, role and the dynamics of the migration networks and their institutionalization help in understanding the importance of the historical analyses of the migration phenomenon. The Gurkha link which has emerged as one of the strongest institutionalized networks in all the countries of South and Southeast Asia has led to the identification of the immense contribution of overseas Nepalis to the economy of Nepal. It also gives a new dimension to the history of migration in Nepal and South and Southeast Asia. The networks play an important role in the historical analyses of the "pioneers of migration, 
reconstitution of migration phases, history of migrant diasporas, returns to the community of origin and behavior of established migrants" (Guilmoto, et. al., 2001, pp.160-161). Historically, perhaps these links had been in existence for as much as 150 years and had been aiding and encouraging migration even before the theory had come into existence. These networks not only encourage migration but also provide the support for settlement and community formation. It has been noticed that new immigrants to the destination country are often provided help with housing and employment. Housing is often within the co-ethnic communities and as such the new migrants get drawn or become included in the society, associations and cultural organizations. They are able to get the physical and emotional support needed for adjustment in a new environment and a way out of their marginality.

However, as is the case with any historical analysis, this is changing in the present century. As mentioned earlier, due to change in immigration policies and emergence of opportunities elsewhere, migrant destinations of the Nepalis are seen to be shifting from South and Southeast Asia to the Middle East and Europe. Though it may take some time before definite patterns are established, one can assume that migration networks would still play a major role in defining migrant destinations as in the case of United Kingdom. Overall, the success of these networks can be evaluated not only in paving way for other migrants, but also in the continuation and sustenance of this movement for the past 200 years now, as in the case of South and Southeast Asia.

\footnotetext{
i The term Gurkha and the Nepali are used interchangeably and refer to the same group of people.

${ }^{\text {ii }}$ Massey et al, 1998 , pp. 42 - 43. Massey also suggested the view that migration networks be seen as a form of social capital, in so far as they are social relations that permit access to other goods of economic significance, such as employment or higher wages.

iii Gorkha(sic) or Gurkha, some 48 miles from Kathmandu, was one of the 24 hill states, the Chaubisi Raj, and was the central province of
} 
what is known as the Kingdom of Nepal. Twenty-two states were of Mongolian origin, while the Gorkha state was ruled by Rajput chieftains who had immigrated from India. Prithvi Narain Shah belonged to this line,(Nath 2003:24).

${ }^{\text {iv }}$ Despite doubts, Lord Amherst, the Governor General 'was fully impressed with the advantage which would arise to the service from increasing the number and strength of the Gorkha (sic) Battalions provided they could be employed in the defense of our eastern frontier or generally in the plains and if necessary in Foreign Service' (Hussain, 2003, p. 68).

${ }^{v}$ Vidya Bir Singh Kansakar, 'International Migration and Citizenship in Nepal" (Population Monograph,http://www.cbs.gov.np/Chapter 14) 93. The Sikhs were a martial kingdom that emerged with the formation of the new sSikh religion under their leader Ranjit Singh. Their state was Punjab with its capital in Lahore, north India and had a friendly alliance with the East India Company, and later the British Raj.

${ }^{\text {vi }}$ The Sylhet Light Infantry (SLI) was drawn mostly from the large body of Settlers from Manipur, and refugees in Sylhet and Cachar in Assam, then known as the Eastern Frontier of British India. In 1828, Lord Bentinck decided to raise two Gurkha companies for the SLI. ${ }^{\text {vii }}$ The largest are the Filipinos, followed by the Indonesians and the Thais. (Stephen Frost, 2004).

viii Of such sites Assam alone has thirteen, Manipur eight, Mizoram and Nagaland seven each, Arunachal Pradesh three and Meghalaya and Tripura one each. Some of these sites are as old as hundred years. ${ }^{\text {ix }}$ Society in Nepal is very much dominated by caste hierarchies based on the Hindu religion and there are strict lines drawn against intermingling between different caste groups.

$x$ "An in-depth study on the situation of Nepalese Domestic Workers in Hong Kong: Summary of Findings" 


\section{References:}

Bolt, D. (1967). Gurkhas. London: Weidenfield and Nicholson.

Castles, S. (2000). Migration as a factor in social transformation in East Asia. Conference on Migration and Development, Princeton University. Retrieved July 2, 2011, from http://www.theglobalsite.ac.uk/press/010castles.pdf.

Castles, S. (2002). Migration and community formation under conditions of globalization. The International Migration Review, 36 (4), Research Library Core.

Collet, N. (1994). The British Gurkha connection in the 1990s. In Michael Hutt, (ed.), Nepal in the nineties: Versions of the past, visions of the future. New Delhi: Oxford University Press.

Census of Nepal, 1911-2000.

Dixit, K M, and Ramachandaran, S. (Eds.) (2002). State of Nepal. Kathmandu: Himal Books.

Dixit, K. M. (1997). Lowly labour in the lowlands. Himal South Asia, 10 (1).

Frey, W. H. (2006). Immigrants are everywhere. Milken Institute Review, Second Quarter.

Stephen, F. (2004). Building Hong Kong: Nepalese labour in the construction sector. Journal of Contemporary Asia, August.

Gargan, E A. (1996, November 2). Gurkhas leaving Hong Kong as sun sets. New York Times, Hong Kong.

Gurung, G., and Adhikari, J. (2004). Problems and prospects of foreign labour migration. In Pong-Sul Ahn (ed.), Migrant workers and human rights: Out-migration from South Asia. International Labour Organization, Geneva, Switzerland.

Guilmoto, C. Z. and Sandron, F. (2001). The internal dynamics of migration networks in developing countries.

Population: An English Selection, 13 (2), 135-164.

Johnston, M., and Light, I. (2007). Identifying and assessing third stage migration network theory. Paper presented at the 
annual meeting of the American Sociological Association, TBA, New York, New York City, Aug 11.

Kansakar, V. B. S. (1982a). Emigration, remittances and rural development. Kathmandu, Nepal, Centre for Economic Development and Administration.

Kansakar, V. B. S. (1982b). International migration and citizenship in Nepal. Population Monograph. Retrieved from http://www.cbs.gov.np .

Kaylor, R. (2000). Enduring tradition of the Gurkhas'(US News and World Report, 6 September,1982), 63-64, cited in Landler, Mark. (1998, October 30). A Hong Kong journal; for fearfully rich, a new fad: a fierce Gurkha, New York Times.

Light, I. et.al. (1990). Migration Networks And Immigrant Entrepreneurship. In California Immigrants in World Perspective: The Conference Papers.

Massey, D. S. (1988). Economic development and international migration in comparative perspective. Population and Development Review, 14, 383-413.

Massey, D.S., et.al. (1998). Worlds in motion: Understanding international migration at the end of the millennium. Oxford, Clarendon Press.

Minami, M. (2008). Overstaying undocumented workers on the decrease in Japan: The case of nepali immigrant workers. In Shinji Yamashita, et.al. (Eds, Transnational migration in East Asia: Japan in comparitive focus (pp. 89-99). Senri Ethnological Reports, Osaka.

Nath, L. (2003). The Nepalis in Assam: Ethnicity and cross border movements in the North East. Kolkata, India, Minnerva Publications.

Nath, 1. (2005). Migrants in flight: Conflict-induced displacement of Nepalis in Northeast India, Peace and Democracy in South Asia, 1, 59-72.

Nath, L. (2006). Migration, insecurity and identity: The Nepali dairymen in India's northeast. Asian Ethnicity,7(2), 129 148.

Nepali workers keen to work in Malaysia. (2002, February 2). The Star. 
O’Malley, L.S.S. (1907). Bengal district gazetteer. Darjeeling, New Delhi (Reprinted ed. 1985).

Priori, M. J. (1979). Birds of passage: Migrant labor in industrial societies. Cambridge: Cambridge University Press.

Seddon, D. (2005). Nepal's dependence on exporting labor. In Migration Information Source. Washington DC, USA: Migration Policy Institute.

Seddon, D., Adhikari, J., and Gurung, G. (2000). Foreign labor migration and the remittance economy of Nepal: A report to DFID. Kathmandu: Overseas Development Group, University of East Anglia, Norwich.

Seddon, D., Adhikari, J., and Gurung, G. (2001). The new Lahures: Foreign employment and the remittance economy of Nepal. The Nepal Institute of Development Studies, Kathmandu.

Shakespeare, L.W. (1929). History of the Assam Rifles. London: Macmillan Co.

The Nepal Institute for Development Studies. (2003). Nepali women workers in foreign lands: Mapping the migration process and contribution to nepali economy and Society. A study conducted for UNIFEM, Kathmandu, unpublished.

Thieme, S. (2007). Social networks and migration: Far west Nepalese labour migrants in Delhi $\left(2^{\text {nd }}\right.$ ed.). NCCR NorthSouth Dialogue, 15, Bern, Switzerland.

Whelpton, J. (2005). A history of Nepal. United Kingdom:

Cambridge University Press.

Yamanaka, K. (2000). Nepalese labor migrants to Japan: From global warriors to global workers. Ethnic and Racial Studies, 23 (1), 62-93.

Dr. Nath is Assistant Professor of History at University of the Incarnate Word, San Antonio, Texas, USA. Email:nath@uiwtx.edu 